DOI: 10.4274/tod.galenos.2020.42103

Turk J Osteoporos 2021;27:1-7

\title{
Development of the Protection Against Osteoporotic Fractures Scale
}

\author{
Osteoporotik Kırıktan Korunma Ölçeği'nin Geliştirilmesi \\ (D) Sultan Aydın, (D) Mehmet Ali Kurçer*, (D) Zeynep Erdoğan** \\ Yalova Provincial Health Directorate, Yalova, Turkey \\ *Zonguldak Bülent Ecevit University Faculty of Medicine, Department of Public Health, Zonguldak, Turkey \\ **Zonguldak Bülent Ecevit University, Ahmet Erdoğan Health Services Vocational School, Department of Medical Services and Techniques, Zonguldak, Turkey
}

\section{Abstract}

Objective: Osteoporosis is a bone disease that increases the risk of fractures. One out of every two women and one out of every five men are at risk for osteoporosis-related fractures during their lifetime. Bone loss can be prevented by taking precautions in every phase of life. To avoid the serious consequences of osteoporosis, healthy behaviours should be supported using theories of health behaviour as a framework. This study aimed to develop protection against osteoporotic fractures (PROF) scale and to test its validity and reliability.

Materials and Methods: This study was conducted among $>55$-year-old female outpatients who were admitted to the orthopaedic clinics of Zonguldak Atatürk Public Hospital. Test-retest was applied via face-to-face interviews. The sample size was calculated to be 10 times the number of scale items, resulting in a sample of 400 participants. The theory of planned behaviour provided the theoretical framework for the PROF scale development. Four strategies have been selected for PROF: (1) Bone mineral density measurement, (2) adherence to treatment, (3) physical exercise and (4) regulations to prevent falls at home.

Results: Factor and matrix correlations of the scale ranged from 0.68 to 0.130 . Test-retest reliability of the whole scale was 0.95 . Cronbach's $\alpha$ value was found to be 0.95 . A strong and statistically significant positive correlation was noted between attitudes and subjective norms pertaining to PROF $(r=0.520 ; 0.525 ; p=0.01$, respectively). A moderate and statistically significant positive correlation was noted between intention and behaviour control $(r=0.462 ; p=0.01)$.

Conclusion: The PROF scale was found to be highly valid and reliable. It can be a part of the public health model aimed at preventing osteoporotic fractures.

Keywords: Osteoporosis, osteoporotic fracture, theory of planned behaviour, scale development, reliability

\section{Öz}

Amaç: Osteoporoz kırık oluşma olasılığının arttığı bir kemik hastalığıdır. Her iki kadından biri, her beş erkekten biri hayatlarının bir döneminde osteoporoz ile ilgili kırık riski altındadır. Her dönemde önlemler alarak kemik kaybı önlenebilir. Osteoporozun ciddi sonuçlarından korunmak için sağ ık davranış teorileri ile sağlık davranışı desteklenmesi gerekir. Bu çalışmada amaç osteoporotik kırıktan korunma (PROF) ölçeğini geliştirmek, geçerlilik ve güvenirliliği göstermektir.

Gereç ve Yöntem: Çalışma Zonguldak Atatürk Devlet Hastanesi'nin Ortopedi Polikliniği'ne ayaktan başvuran 55 yaş üstündeki kadınlarda yürütülmüştür. Yüz yüze görüşme tekniği kullanılarak test re-test yapılmışıı. Örneklem seçilmeden, örneklem sayısı madde sayısının on katı olarak 400 hesaplanmıştır. Planlı davranış teorisi model olarak alınmıştır. Niyet ve davranış bağımlı değişkenlerdir. Tutum, öznel norm ve davranış kontrolü bağımsız değişkenlerdir. PROF'de dört strateji: 1) Kemik mineral yoğunluğu ölçümü, 2) tedaviye uyum, 3) fiziksel egzersiz ve 4) evde düşmeyi önleyecek düzenlemeler seçilmiştir.

Bulgular: PROF niyeti ile tutum ve öznel norm arasında istatistiksel olarak pozitif yönde, güçlü ve anlamlı bir ilişki vardır (sırasıyla $r=0,520$; $0,525 ; p=0,01)$. Davranış kontrolü ile niyet arasında istatistiksel olarak pozitif yönde, orta güçte ve anlamlı bir ilişki vardır $(r=0,462 ; p=0,01)$. Güvenirlilik Cronbach $\alpha$ değeri 0,95'dir.

Sonuç: PROF için geliştirilen ölçek yüksek güvenirlilik ve geçerliliğe sahiptir. Osteoporotik kırıklarla mücadelede halk sağlığı modellerinin bir parçası olabilir.

Anahtar kelimeler: Osteoporoz, osteoporotik kırık, planlı davranış teorisi, ölçek geliştirme, güvenirlilik

Address for Correspondence/Yazışma Adresi: Zeynep Erdoğan Assoc. Prof., Zonguldak Bülent Ecevit University, Ahmet Erdoğan Health Services Vocational School, Department of Medical Services and Techniques, Zonguldak, Turkey

Phone: +90 3722613265 E-mail: zeynerdogan@hotmail.com ORCID ID: orcid.org/0000-0002-7298-7559

Received/Geliş Tarihi: 06.09.2019 Accepted/Kabul Tarihi: 07.01.2020

${ }^{\circ}$ Copyright 2021 by the Turkish Osteoporosis Society / Turkish Journal of Osteoporosis published by Galenos Publishing House 


\section{Introduction}

Osteoporosis (OP) is the most common bone disease. OP is a skeletal system disease with increased risk for fractures and is characterized by reduced bone mineral density (BMD) and deteriorations in the bone tissue microstructure. According to the 2004 report of the World Health Organization, more than 200 million people suffer from OP and approximately $40 \%$ of affected people consist of females and people older than 50 years of age. Optimal power-flows (OPF) constitute approximately $1 \%$ of disability-adjusted life years pertaining to chronic diseases (1).

There are various risk factors for OP due to its multifactorial nature. Behaviors such as healthy nutrition, adequate physical activity, sensible medicine use, smoking cessation, and avoiding excessive alcohol consumption are important for protection against OP (2). Behaviors which promote bone development including sufficient calcium intake and regular weightlifting may decrease the risk for $\operatorname{OP}(2,3)$. Despite the well-documented benefits of exercise, aging women keep pursuing a sedentary lifestyle (4). Health education is a powerful instrument in terms of protection against OP and its consequences. Health behavior and lifestyle changes can be complex (5).

The theory of planned behavior (TPB) proposes a model which can measure how human behavior is shaped. The TPB investigates beliefs and attitudes that underlie health behaviors. According to this model, intention predicts the formation of a deliberate behavior (6).

TPB is determined by three conceptually independent constructs: attitudes towards a behavior, subjective norms, and behavior control. These three behaviors determine attitudes towards a behavior $(7,8)$. Subjective norms are based upon the belief that reference person or groups approve the behavior (9). TPB is a health promotion theory for optimizing OPF. There wasn't any study which to promote positive health behaviors about OPF which was based on the TPB.

The aim of this study was to develop the protection against osteoporotic fractures (PROF) scale based on the TPB model.

\section{Materials and Methods}

In this study, based on the TPB model, a measure for protection against osteoporotic fractures in postmenopausal women was developed.

The current study was carried out at the Zonguldak Atatürk Public Hospital Orthopedic Clinics, which is located in the city of Zonguldak. The annual number of outpatients admitted to these clinics is 66,256 . Universe of the study consisted of postmenopausal women aged above 55 years who admitted to the Zonguldak Atatürk Public Hospital Orthopedic Clinics. The study sample included postmenopausal women aged above 55 years who were outpatients and who were willing to participate in the study. Each patient was informed about the study and written consent was taken from the patients.

Sample size was determined by multiplying the number of items
(40 items) by 10 , resulting in a sample size of 400 participants $(10,11)$. The study was conducted with 400 outpatients who admitted to the hospital from May, $21^{\text {st }}$ to September, $10^{\text {th }}$ of the year 2015 .

Inclusion criteria: Being a postmenopausal women aged 55 years and above, not undergoing major surgery during the last 2 months, not having an amputation.

Limitations: The sample does not represent all postmenopausal patients since it consisted of volunteering outpatients admitted to an orthopedic clinic. The follow-up period was 6 months and may not be of adequate length in terms of observing the consequences of behavior in the long run.

\section{Definitions and Criteria Related to PROF Scale Variables}

The PROF scale was developed according to the TPB. The variables "Attitude", "Subjective Norm", and "Perceived Behavior Control", which affect "Intention", the core of the model, were primary variables. Secondary variables/determinants of the model were beliefs measured through "Behavioral Beliefs", "Normative Beliefs", and "Control Beliefs". Notably, the role of past behavior, in addition to accounting for the influence of habitual behavior in intention and behavior, are evident in earlier studies (6). Therefore, it was decided that the past behavior should be included in the PROF scale.

In the study, 5-point Likert type response categories ranged from "I absolutely disagree" (1) to "I totally agree" (5). Since only the control beliefs difficulties part were negatively worded, the 5-point Likert type responses ranged from "I absolutely disagree" to "I totally agree" $(1,5)$.

The scale was prepared based on the TPB model, which is one of the health promotion models for developing target behaviors $(7,9)$. In the PROF scale, four target activities aimed at protecting women against OPF's included maintaining a calcium-rich dietsunbathing, use of OP medication when necessary, daily physical activity-programmed exercises, and new house arrangements to prevent falls. Each activity was adapted to the TPB model. For each strategic precaution, the TPB was used to create a pool of 98 items. Forty items were selected from the item pool for draft of PROF scale. Higher scores indicated higher levels of protection, while lower scores indicated insufficient protection. For a standard TPB based study, a draft scale was formed by 5 experts. According to the opinions of the experts, the items that were stated to be problematic were corrected in line with the recommendations and 98 items were subtracted and a draft scale consisting of 40 items was created. Thus, content validity was established. Reliability was tested using the test-retest method, where the scale was readministered after a two week interval.

Ethical approval was obtained from the Bülent Ecevit University Faculty of Medicine Clinical Research Ethics Committee (protocol no: 2015-18-20/05). Administrative permission to conduct the study was obtained from the Zonguldak Public Hospital (document numbered 79914002/900 and record 
numbered 7201). Two interviews and a test-retest application were conducted with each volunteering patient via the face-toface interview method. Data was collected from 400 patients using the sociodemographic data form and the PROF scale. Participants answered the PROF scale by selecting one of the 5-point Likert type response categories (12). Also a questionary which contained a12-item information form questioning sociodemographic and OPF's related characteristics was used.

\section{Statistical Analysis}

Statistical analysis of the study was conducted using the SPSS 19.0. Data was tested for normality using the Shapiro-Wilk test. The Mann-Whitney U test was applied to non-normally distributed variables in 2 group comparisons, while the Kruskal-Wallis test was used for 3 group comparisons. Spearman correlation analysis was used to examine the relationship between the variables. Factor analysis was used to determine the subscales of the scale. Cronbach alpha $(\mathrm{Cr} \alpha)$ internal consistency coefficient was calculated in evaluating the reliability of the scale. Level of statistical significance was set at $p<0.05$.

\section{Reliability Analyses}

Two different methods of reliability, namely internal consistency and time validity, were used of assessing the reliability of the draft of PROF scale which includes 40 items. In order to evaluate reliability, $\mathrm{Cr} \alpha$ internal consistency coefficient was first calculated. $\mathrm{Cr} \alpha$ is an appropriate internal consistency method when response categories range from 1 to 5 (13). $\mathrm{Cr} \alpha$ internal consistency coefficient is calculated by dividing the total item variance to the general variance. This coefficient may range from 0 to 1 . A value over 0.70 indicates high levels of reliability (14). The test-retest technique, which evaluates invariance of test scores over time, was used by examining the correlation between pre- and posttest results. For establishing content validity, the content of the scale was logically evaluated by four experts. In order to be able to discover and reveal the dimensions of the scale, a principal components analysis (PCA), which is one of the exploratory factor analysis (EFA) methods, was carried out. To determine the factor structure of the scale, a principal component analysis with varimax rotation, which is a linear rotation technique, was conducted. In factor analysis, factor loadings of 0.60 and above was considered as high, while 0.30-0.59 was considered as moderate loading, regardless of plus and minus signs (14). In the current study, a total of 22 items with rotated factor loadings above 0.30 were included in the factorial construct.

In order to be able to discover and reveal the dimensions of the scale that are required in the scale development process. Confirmatory factor analysis (CFA) procedures were conducted, and all analyses were carried out using the AMOS Version 4.1 software. Data were analyzed in five stages: (1) we conducted EFA with half of the sample using maximum likelihood extraction with oblique rotation using structural equation modeling statistics package AMOS 6.0 (2). We confirmed the fit of the generated factor structure in the second half of the sample by conducting CFA (3).
Extraction and rotation; to determine the factor structure of the scale, principal component analysis was performed with orthogonal (Varimax) rotation, which is a linear rotation technique $(11,12)$. In this study, 22 items with a factor load of 0.30 after rotation were included in the factor structure. Thus, 18 items from the load of 0.29 were removed from the draft scale.

\section{Results}

The mean age of the 400 patients was $62.7 \pm 7.17$. Patients were at the least 55 years old and at the most 86 years old. It was found that $68.5 \%$ were married, $31.5 \%$ were single, and $10.3 \%$ live alone. Among the participants, 79.1\% were housewives, 9.3\% were retired, $6.8 \%$ were in paid employment, and $4.8 \%$ reported to be unable to work. Of the women, $43.5 \%$ were illiterate, $11.3 \%$ were literate, $30.2 \%$ were elementary school graduates, $8.5 \%$ were high school graduates, and $6.5 \%$ were university graduates.

It was found that $80.8 \%$ of women were active at home or outside on a daily life (house chores, gardening, shopping).

Among the participants, 35.8\% stated that they never fell, $45.5 \%$ said they had fallen but did not have bone fractures, $16.3 \%$ had a fracture, and $2.5 \%$ had multiple fractures. For BMD measurements, bone scan was "never done" in 37.0\% of the participants, was done at least once in $63.0 \%$, and was frequently and/or completely done in $9.6 \%$. It was found that $44.8 \%$ of the patients never adhered to doctors' medical advice and nutrition recommendations, $32.3 \%$ reported to minimally adhere, and $10.8 \%$ reported to completely adhere. Among the participants, $63.5 \%$ of patients did not regularly engage in physical exercise in the last year, $20.4 \%$ rarely exercised, and $6.9 \%$ frequently exercised. Of the participants, $63.3 \%$ said that they did not make any arrangements in their houses to prevent falling, $19.2 \%$ did minimal arrangements, and $5.8 \%$ did considerable arrangements.

TPB variables and retest reliability of the PROF scale test were given in Table 1. The PROF scale had a $\mathrm{Cr} \alpha$ coefficient of 0.95 , while the $\mathrm{Cr} \alpha$ coefficients of the variables ranged from 0.70 to 0.89 . Test-retest reliability of the entire scale was $0.95(p<0.01)$ and the test-retest reliability of the variables were 0.72-0.90.

Suitability of data for factor analysis was examined using the $\mathrm{KMO}$ value, which was found to be 0.90 (excellent). The Bartlett Sphericity value was $p=0.001$ and below 0.10 . These two values indicate that factor analysis can be conducted.

To test construct validity, an exploratory analysis, the PCA, was initially used. Items with factor loadings above 0.30 were determined and the PROF scale was reduced to 22 items. A varimax rotation was conducted, resulting in 6 factors with Eigenvalues above 1. Factor 1 accounted for $36.44 \%$ of the total variance, factor 2 accounted for $8.49 \%$, factor 3 accounted for $7.15 \%$, factor 4 accounted for $4.85 \%$, factor 5 accounted for $4.22 \%$, and factor 6 accounted for $3.87 \%$. In the study, total variance was found to be $65.0 \%$. The 28 -item factor structure 
and total variance of the PROF scale was provided in Table 2. Table 2 shows the matrix structure of the PROF scale. The items grouped under 6 factors. Sixteen items were removed from the scale.

Factor matrix structure of the sub scales of the PROF scale were given in Table 3 and 4.

Correlations between variables fromed in accordance with the TPB model were shown in Table 4.

A final confirmatory model was proposed that had structure with the six factors being nested within structure of PROF scale. This model also passed the fit criteria, and the results are given at the bottom of Table 5 .

CFA model goodness fit indexes of PROF scale with 22 items were very high Table 5.

Relative chi-square index (CMIN/DF) value was found to be 3.41. This value is considered sufficient for the model to be accepted. The adjusted goodness-of-fit index value of 0.834 , the goodness-of-fit index (GFI) value of 0.870, the comparative fit index (CFI) value of 0.900. Approximation of the GFI and CFI values to 1 indicates increased compliance. Root mean square of the residuals of 0.078 indicates that the goodness of fit is high. Based on the post-deposition treatment (PDT), the initial 40-item model CFA. According to their calculations, the model was not considered acceptable when looking at the goodness of fit indexes. PROF scale CFA model fit goodness indices The DFA model goodness of fit index of the 22-item. A final confirmatory model was proposed which had the structure of the six factors being nested within the structure of PROF scale. The model also passed the fit criteria, and the results were given at the bottom of Table 5 .

In Figure 1 CFA standardized regression coefficients and factor correlation values were seen. There were positive strong correlation with F1 and four factors F2 ( $r=0.532)$, F4 ( $r=0.707)$,
F5 $(r=0.803)$ and F6 $(r=0.614)$. There were were positive strong correlation with F2 and two factors F5 $(r=0.571)$ and $\mathrm{F} 6(\mathrm{r}=0.614)$. Also F4 and F5 were positive strong correlated $(r=0.614)$.

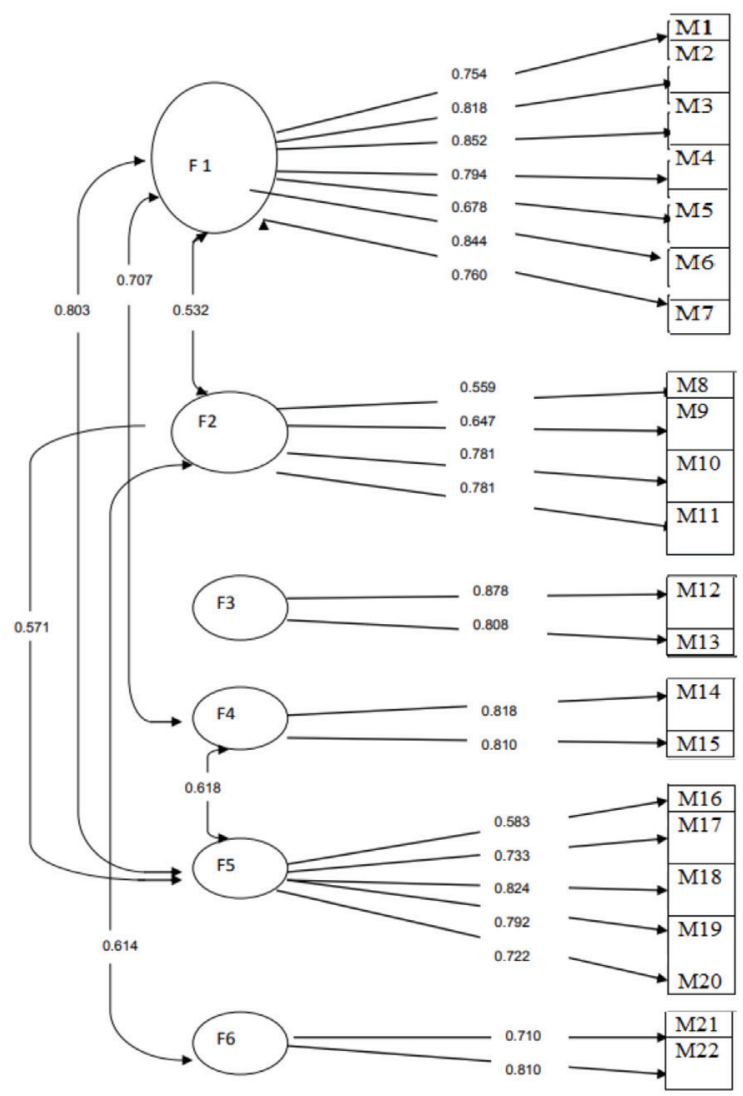

Figure 1. First-level exploratory factor analysis with standardized results

Table 1. Theory of planned behavior variables of protection against osteoporotic fractures scale test and re-test reliability

\begin{tabular}{|c|c|c|c|}
\hline Factors & Items & Test $\mathrm{Cr} \alpha$ & Re-test $\operatorname{Cr} \alpha$ \\
\hline 1- Behavioral beliefs (items: 1-7) & 7 & 0.82 & 0.83 \\
\hline 2- Intention (items: 8-11) & 4 & 0.70 & 0.76 \\
\hline 3- Past behavior (items: 12-13) & 2 & 0.73 & 0.72 \\
\hline 4- Subjectif norm (items: 14-15) & 2 & 0.84 & 0.85 \\
\hline 5- Perceived behavioral control (items: 16-20) & 5 & 0.86 & 0.85 \\
\hline 6- Attitute (items: 21-22) & 2 & 0.71 & 0.72 \\
\hline Total & 22 & 0.95 & 0.95 \\
\hline
\end{tabular}

Table 2. The factor variance and total variance of the protection against osteoporotic fractures scale

\begin{tabular}{|l|l|l|l|l|}
\hline Factor & Eigenvalue & Variance total & Variance & Number of items \\
\hline 1 & 10.20 & 36.44 & 36.44 & 7 \\
\hline 2 & 2.37 & 8.49 & 44.93 & 4 \\
\hline 3 & 2.00 & 7.15 & 52.09 & 2 \\
\hline 4 & 1.36 & 4.85 & 56.95 & 2 \\
\hline 5 & 1.82 & 4.22 & 61.17 & 5 \\
\hline 6 & 1.08 & 3.87 & 65.4 & 2 \\
\hline
\end{tabular}




\begin{tabular}{|c|c|c|}
\hline Items & English version of PROF items & $\mathbf{r}$ \\
\hline \multicolumn{3}{|c|}{ Behavioral beliefs (F1) } \\
\hline 1 & If I know about the proper physical exercises I can do, it will be easier for me to do physical exercise. & 0.778 \\
\hline 2 & $\begin{array}{l}\text { If you exercise physically, you will be protected from bone fractures, and you will live longer without being } \\
\text { dependent on anyone. }\end{array}$ & 0.743 \\
\hline 3 & If I have knowledge about anti-dumping domestic regulations, it will be easier to take measures. & 0.657 \\
\hline 4 & $\begin{array}{l}\text { It will be easier for me to follow the recommendation if I know about the medical treatment or supplemental } \\
\text { support recommended by the doctor. }\end{array}$ & 0.645 \\
\hline 5 & $\begin{array}{l}\text { If I apply the medical treatment recommendations that my doctor recommends, I should be protected from } \\
\text { bones and fractures. }\end{array}$ & 0.636 \\
\hline 6 & Physical exercise is difficult for me. & 0.613 \\
\hline 7 & It is difficult for me to arrange it in the house to prevent falling. & 0.545 \\
\hline \multicolumn{3}{|c|}{ Intention (F2) } \\
\hline 8 & I intend to measure BMD at certain intervals. & 0.694 \\
\hline 9 & $\begin{array}{l}\text { I intend to comply with the medical treatment or supplementary advice suggested by my doctor to protect } \\
\text { from bone erosion. }\end{array}$ & 0.678 \\
\hline 10 & I intend to make an arrangement to prevent my home from falling within a year. & 0.678 \\
\hline 11 & I want to make arrangements in the house to prevent falling. & 0.653 \\
\hline \multicolumn{3}{|c|}{ Past behavior (F3) } \\
\hline 12 & I have done BMD measurements at certain intervals until now. & 0.887 \\
\hline 13 & $\begin{array}{l}\text { I applied the medical treatment or supplementary advice suggested by the doctor to protect from bone } \\
\text { marrow. }\end{array}$ & 0.904 \\
\hline
\end{tabular}

\section{Table 4. Factor matrix structure of the some sub scales (F4-6) of the protection against osteoporotic fractures scale}

\begin{tabular}{|l|c|l}
\hline Items & English version of PROF items & $r$
\end{tabular}

\section{Subjectif norm (F4)}

\begin{tabular}{|l|l|l|}
\hline 14 & My family and friends are welcomed to exercise physical exercise in order to avoid bone loss. & 0.600 \\
\hline 15 & My family and my friends hopes to make a new arrangement in the house to prevent the fall. & 0.599
\end{tabular}

\section{Perceived behavioral control (F5)}

\begin{tabular}{|l|l|l|}
\hline 16 & I want to do proper physical exercise. & 0.694 \\
\hline 17 & It is necessary to make a new arrangement in the house to prevent falling. & 0.678 \\
\hline 18 & I have the ability to make arrangements inside the house to prevent falling. & 0.678 \\
\hline 19 & I have a BMD measure. & 0.653 \\
\hline 20 & There is a medical practitioner's advice on medical treatment or supplementary advice. & 0.636 \\
\hline Attitute (F6) & 0.744 \\
\hline 21 & It is necessary to carry out BMD measurements at certain intervals. & 0.778 \\
\hline 22 & It is necessary to follow the ecommendations of the doctor for medical treatment or supplementary support. & \\
\hline BMD: Bone mineral density, PROF: Protection against osteoporotic fractures
\end{tabular}

\section{Discussion}

The Centers for Disease Control determined people who needed screening. Screening is recommended for Caucasian women aged 65 years or above without any additional risk factors, while it is recommended for younger women who are at risk for OP and fractures (15). Since there are no scales on protection against fractures based on the TPB model, an EFA was undertaken in the current study in order to explore an empirical construct $(15,16)$. According to the results of the factor analysis, which was conducted in order to test the construct validity of the PROF scale, 28 items with factor loadings ranging from 0.39 to 0.77 
Table 5. Confirmatory factor analysis model goodness fit indexes of protection against osteoporotic fractures scale with 22 items

CFA model goodness fit indexes of PROF-scale with 22 items

\begin{tabular}{|l|l|l|l|l|l|l|l|l|}
\hline$\chi^{2}$ & DF & p & CMIN/DF & AGFI & GFI & CFI & RMSEA \\
\hline 734,334 & 215 & 0.001 & 3.416 & 0.834 & 0.870 & 0.900 & 0.078 \\
\hline CFA model goodness fit indexes of PROF-scale with & 40 items \\
\hline 2894.065 & 568 & 0.001 & 5.095 & 0.614 & 0.671 & 0.763 & 0.101 \\
\hline
\end{tabular}

CFA: Confirmatory factor analysis, DF: Degree of freedom, CMIN/DF: Relative chi-square index, AGFI: Adjusted goodness-of-fit index, GFI: Goodness-of-fit index, CFI: Comparative fit index, RMSEA: Root mean square of the residuals, PROF: Protection against osteoporotic fractures

were grouped under 6 factors. The 6 factors explained $65 \%$ of the total variance. Measurements taken from the same patients were found to be highly reliable. The $\mathrm{Cr} \alpha$ coefficient of the entire scale was 0.95 and ranged from 0.70 to 0.89 for the subscales. The factor and matrix correlations of the scale varied from 0.68 to 0.130 . Test-retest reliability of the entire scale was 0.95 and varied from 0.72 to 0.90 for the subscales. Accordingly, it was demonstrated that the PROF scale was valid and reliable. There was a strong and positive correlation between womens' intentions to protect against OPF's and subjective norms. Women who had positive attitudes towards BMD measurement and medicine use (93\% and $85 \%$, respectively) had higher intention scores. Women who had positive attitudes towards physical exercise and making arrangements to prevent falling (73\% and $70 \%$, respectively) had lower intention scores. High rates of BMD measurement and medicine use $(75 \%$ and $65 \%$, respectively) in women who perceived the effect of subjective norm values on intention as social pressure from the family indicated that family is a positive element for social pressure. There was a positive and moderate correlation between intention and perceived behavioral control. Perceived behavior control was evaluated in terms of opportunities and possibilities. Accordingly, $88 \%$ of the participants had the opportunity to have a BMD measurement, $84 \%$ had the opportunity to apply medical treatment and recommendations, $61 \%$ had the opportunity to engage in physical exercise, and $57 \%$ had the opportunity to make house arrangements to prevent falls. There was a strong and positive relationship between perceived behavior control and control beliefs. Behavior control was evaluated in terms of opportunities and possibilities. Accordingly, $88 \%$ of the participants had the opportunity to have a BMD measurement, $84 \%$ had the opportunity to apply medical treatment and recommendations, $61 \%$ had the opportunity to engage in physical exercise, and $57 \%$ had the opportunity to make house arrangements to prevent falls.

There was a strong and positive relationship between subjective norms and normative beliefs. In normative belief evaluation, it was thought that families would positively respond to BMD measurements and adherence to medicines and medical recommendations (90\% and $77 \%$, respectively) and physical exercise and house arrangements (70\% and 65\%, respectively). The women reported to be willing to have a BMD measurement $(92 \%)$, to adhere to medicines and medical recommendations
(85\%), to engage in appropriate physical exercise (60\%), and to make house arrangements to prevent falling (50\%).

A moderate and positive relationship was found between attitudes and behavioral beliefs. In terms of behavioral beliefs, $90 \%$ of the women believed that they can discover whether they have OP or not if they had a BMD measurement, 75\% believed that they can protect themselves against OP and OPF's if they adhere to medical treatment and recommendations, $73 \%$ believed that they can protect themselves against OP and OPF's and live independently for a long time if they engaged in appropriate physical exercise, and $73 \%$ believed that they can decrease the risk for OPF's if they make house arrangements to prevent falls. In order to increase the rate of physical exercise in this population, public health interventions regarding exercise beliefs may prove to be beneficial.

The concepts of PDT were beneficial in terms of understanding commitment to exercise programs or participation in leisure time physical activity (12). In studies which underlined the importance of exercise habits in term of predicting exercise behavior, personal beliefs which were affected by affective interests and social importance predicted intentions. Perceiving regular exercise as a difficult thing and taking or not taking personal responsibility regarding exercise depend upon beliefs (17). It is important to protect the spine by engaging in appropriate daily exercises (18). The belief that falls can be prevented should be supported.

\section{Study Limitations}

This study was conducted with female outpatients who were above 55 years of age and who admitted to the orthopedic clinics of Zonguldak Atatürk Public Hospital and cannot be generalized to all female outpatients.

\section{Conclusion}

Four out of every five women are active at home or outside, while one is not. Of the women, 65\% fell at least once and among those who fell, $69 \%$ did not have a fracture as a result and $31 \%$ had at least one fracture. One fifth of the sample had an orthopedic surgery during adulthood. Approximately one fourth of the women used an optic or hearing device, while one tenth used assistive walking devices or more than one device. Among the women, 37\% never had a BMD measurement, 45\% never adhered to medical treatment and recommendations, and $63 \%$ never engaged in physical exercise and never made house 
arrangements to prevent falling.

The study demonstrated that the majority of women (91\%) intended to have a BMD measurement, $87 \%$ intended to adhere to medicines and medical recommendations, $60 \%$ intended to engage in appropriate physical exercise, and only $50 \%$ intended to make house arrangements to prevent falling. 88\% believed that it would be easier to have a BMD measurement if they increased their knowledge on the subject, $70.7 \%$ believed that it would be easier to adhere to medicines and medical recommendations if they increased their knowledge on the subject, $65 \%$ believed that it would be easier to engage in appropriate physical exercise if they increased their knowledge on the subject, and $68 \%$ believed that it would be easier to make house arrangements to prevent falling if they increased their knowledge on such arrangements.

The scale had a very high reliability coefficient $(\mathrm{Cr} \alpha 0.95)$. Testretest reliability was also high. The PROF scale was reduced to 28 items by selecting items with factor loadings between 0.39 and 0.77 . It was determined that the scale had 6 factors. A strong and positive relationship was found between intentions to protect against OPF's and attitudes and subjective norms, while a moderate and positive association was found between intentions and behavior control. Attitudes and behavioral beliefs were moderately and positively correlated, behavior control and control beliefs were strongly and positively correlated, and subjective norms and normative beliefs were strongly and positively correlated. This self-report scale evaluates how well postmenopausal women protect themselves against OPF's and provides a comprehensible framework by providing strategic steps to develop health behaviors. This scale can be a part of public health models aimed at fighting postmenopausal OP and OPF's.

\section{Ethics}

Ethics Committee Approval: Ethical approval was obtained from the Bülent Ecevit University Faculty of Medicine Clinical Research Ethics Committee (protocol no: 2015-18-20/05).

Informed Consent: Each patient was informed about the study and written consent was taken from the patients.

Peer-review: Externally peer-reviewed.

\section{Authorship Contributions}

Surgical and Medical Practices: S.A., Concept: S.A., M.A.K., Design: S.A., M.A.K., Data Collection or Processing: S.A., Analysis or Interpretation: S.A., M.A.K., Z.E., Literature Search: S.A., M.A.K., Z.E., Writing: S.A., M.A.K., Z.E.

Conflict of Interest: No conflict of interest was declared by the authors.

Financial Disclosure: The authors declared that this study has received no financial support.

\section{References}

1. WHO Scientific group on the assessment of osteoporosis at primary health care level. Summary Meeting Report. Brussels, Belgium, 5-7 May 2004. http://www.who.int/chp/topics/Osteoporosis.

2. Elffors I, Allander E, Kanis JA, Gullberg B, Johnell O, Dequeker J, et al. The variable incidence of hip fracture in southern Europe: the MEDOS Study. Osteoporos Int 1994;4:253-63.

3. Johnell O, Gullberg B, Kanis JA, Allander E, Elffors L, Dequeker J, et al. Risk factors for hip fracture in European women: the MEDOS Study. Mediterranean Osteoporosis Study. J Bone Miner Res 1995;10:1802-15.

4. O'Donoghue G, Perchoux C, Mensah K, Lakerveld J, van der Ploeg $\mathrm{H}$, Bernaards $\mathrm{C}$, et al. A systematic review of correlates of sedentary behaviour in adults aged 18-65 years: a socio-ecological approach. BMC Public Health 2016;16:163.

5. Mark S, Link $H$. Reducing osteoporosis: prevention during childhood and adolescence. Bull World Health Organ 1999;77:4234.

6. Ajzen I. The theory of planned behavior. Organizational Behavior and Human Decision Processes 1991:50;179-211.

7. Francis JJ, Eccles MP, Johnston M, Walker A, Grimshaw J, Foy R, et al. Constructing Questionnaires Based On The Theory Of Planned Behaviour: A Manual For Health Services Researchers. Newcastle: Centre for Health Services Research University press; 2004.

8. Ajzen I. Attitudes, Personality and Behavior. Milton-Keynes, England Open University Press: McGraw-Hill International; 2005.

9. Cialdini RB. Influence: Science and practice. 4th ed. Boston: Allyn \& Bacon; 2001

10. Kallgren CA, Reno RR, Cialdini RB. A focus theory of normative conduct: When norms do and do not affect behavior. Personality and Social Psychology Bulletin 2000;26:1002-12.

11. Büyüköztürk S. Scientific Research Methods. Series of Educational Classics. Ankara: Pegem Academy Publishing; 2013.

12. Büyüköztürk $S$, Çokluk $O$, Köklü N. Statistics for Social Sciences. Ankara: Pegem Academy Publishing / Publishing House General Series; 2010.

13. Eser E, Fidaner H, Fidaner C, Yalçin Eser S, Elbi H, Göker E. Psychometric properties of the WHOQOL-100 and WHOOOLBREF.3P Psychiatry Psychology Psychopharmacology Journal 1999;7:23-40.

14. Ercan i, Kan i. Reliability and validity in the scales. Journal of Uludağ University Faculty of Medicine 2004;30:211-6.

15. Czerwiński E, Badurski JE, Marcinowska-Suchowierska E, Osieleniec J. Current understanding of osteoporosis according to the position of the World Health Organization (WHO) and International Osteoporosis Foundation. Ortop Traumatol Rehabil 2007;9:33756.

16. Recommendation-Summary/Osteoporosis-Screening. USPSTF U.S Preventive Services Task Force. Original Release Date: January 2011. http://www.uspreventiveservicestaskforce.org. Last Access date: 27.12 .2018

17. Valois P, Desharnais R, Godin G. A comparison of the Fishbein and Ajzen and the Triandis attitudinal models for the prediction of exercise intention and behavior. J Behav Med 1988;11:459-72.

18. NOF's Clinician's Guide to Prevention and Treatment of Osteoporosis. https://my.nof.org/bone-source/education/ clinicians-guide-to-the-prevention-and-treatment-of-osteoporosis List of Updates: 2015.11.11. Last Access date: 27.12.2018. 